\title{
N:K RATIO FOR PHENOLOGICAL GROWTH STAGES OF NET MELON CULTIVATED IN NFT HYDROPONIC SYSTEM ${ }^{1}$
}

\author{
CAMILA SENO NASCIMENTO² ${ }^{2}$ CAROLINA SENO NASCIMENTO² ${ }^{2}$, ARTHUR BERNARDES CECÍLIO FILHO ${ }^{2 *}$
}

\begin{abstract}
The adequate ratio in the supply of nitrogen $(\mathrm{N})$ and potassium $(\mathrm{K})$ for each phenological growth stage of melon is fundamental for its growth and development with the maximization of the dry mass partition between the vegetative and reproductive parts. The objective of this study was to evaluate the influence of $\mathrm{N}$ and $\mathrm{K}$ concentrations in two phenological growth stages (vegetative and reproductive stage) of melon and obtain the best $\mathrm{N}: \mathrm{K}$ ratio for each one. In the first stage, four concentrations of $\mathrm{N}(8,11,14$ and $\left.17 \mathrm{mmol} \mathrm{L}^{-1}\right)$ and two concentrations of $\mathrm{K}\left(4\right.$ and $\left.5 \mathrm{mmol} \mathrm{L}^{-1}\right)$ were evaluated in a randomized block design in a $4 \times 2$ factorial scheme with five replicates. In the second stage, in a $2 \times 2$ factorial scheme, the combinations of the two concentrations of $\mathrm{N}$ that generated the best characteristics in the previous stage and two concentrations of $\mathrm{K}$ (4.5 and $9.0 \mathrm{mmol} \mathrm{L}^{-1}$ ) were evaluated. The increase of the $\mathrm{N}$ concentration in the vegetative stage promoted the increase of the N, P and S content of leaves and the reduction of $\mathrm{K}, \mathrm{Ca}$ and $\mathrm{Mg}$. Moreover, it increased the number of leaves, the height of the plant (vertically tutored) and the leaf area. Therefore, 17:5 mmol L-1 was considered as the best $\mathrm{N}: \mathrm{K}$ ratio for the vegetative stage. In the second stage, there was no effect of $\mathrm{N}$ and $\mathrm{K}$ concentrations on leaf area, yield and fruit quality. So, 14:4.5 mmol L${ }^{-1}$ was considered as the best $\mathrm{N}: \mathrm{K}$ ratio for the reproductive stage.
\end{abstract}

Keywords: Cucumis melo. Mineral nutrition. Protected cultivation. Soilless cultivation.

\section{RELAÇÃO N:K PARA OS ESTÁDIOS FENOLÓGICOS DE MELÃO RENDILHADO CULTIVADO EM HIDROPONIA}

RESUMO - A adequada relação no fornecimento de nitrogênio $(\mathrm{N})$ e potássio $(\mathrm{K})$ para cada estádio fenológico do meloeiro é fundamental para seu crescimento e desenvolvimento, com maximização da partição de massa seca entre as partes vegetativas e reprodutivas. O objetivo deste trabalho foi avaliar a influência de concentrações de $\mathrm{N}$ e $\mathrm{K}$ para duas fases fenológicas (vegetativa e reprodutiva) do meloeiro e obter a melhor relação $\mathrm{N}: \mathrm{K}$ para cada uma delas. Na primeira fase, foram avaliadas quatro concentrações de $\mathrm{N}(8,11,14 \mathrm{e}$ $\left.17 \mathrm{mmol} \mathrm{L}^{-1}\right)$ e duas concentrações de $\mathrm{K}\left(4\right.$ e $\left.5 \mathrm{mmol} \mathrm{L}^{-1}\right)$, em delineamento experimental de blocos ao acaso, em esquema fatorial $4 \times 2$, com cinco repetições. Na segunda fase, em esquema fatorial $2 \times 2$, foram avaliadas as combinações das duas concentrações de $\mathrm{N}$ que geraram as melhores características na fase anterior e duas concentrações de $\mathrm{K}\left(4,5\right.$ e $\left.9,0 \mathrm{mmol} \mathrm{L} \mathrm{L}^{-1}\right)$. O aumento da concentração de $\mathrm{N}$ na fase vegetativa promoveu o aumento dos teores foliares de N, P e S e a redução de $\mathrm{K}, \mathrm{Ca}$ e $\mathrm{Mg}$. Além disso, aumentou o número de folhas, a altura da planta (tutorada verticalmente) e a área foliar. Por isso, 17:5 $\mathrm{mmol} \mathrm{L}^{-1}$ foi considerada como melhor relação $\mathrm{N}: \mathrm{K}$ para a fase vegetativa. $\mathrm{Na}$ segunda fase, não houve efeito das concentrações de $\mathrm{N}$ e de $\mathrm{K}$ sobre a área foliar, produtividade e a qualidade dos frutos do meloeiro e, assim, considerou-se 14:4,5 mmol L-1 como a melhor relação $\mathrm{N}: \mathrm{K}$ para a fase reprodutiva.

Palavras-chave: Cucumis melo. Nutrição mineral. Cultivo protegido. Cultivo sem solo.

\footnotetext{
${ }^{*}$ Corresponding author

${ }^{1}$ Received for publication in $07 / 26 / 2019$; accepted in $12 / 16 / 2019$.

Paper extracted from the master's dissertation of the first author.

${ }^{2}$ Department of Plant Production, Universidade Estadual Paulista "Júlio de Mesquita Filho", Jaboticabal, SP, Brazil; camilaseno@gmail.com - ORCID: 0000-0003-2558-5765, senocarolina@gmail.com - ORCID: 0000-0002-8096-5392, arthur.cecilio@unesp.br - ORCID: 0000-0002-6706-5496.
} 


\section{INTRODUCTION}

Melon (Cucumis melo) is a widely grown crop in several countries due to its high economic value and excellent acceptance into national and international markets (SUN et al., 2017). In 2017, Brazil was the thirteenth largest melon producer in the world with a production of approximately 540 thousand tons of fruit (FAO, 2017). Most of these fruits were destined for the foreign market, being one of the most economically significant fruit crops in the country.

As a crop with high potential for fruit and dry matter production, melon demands a large amount of fertilizer per unit area, being that, the inadequate supply of nutrients can cause physiological disturbances and affect the yield and the quality of fruits (DEUS et al., 2015). The nutrient requirements of the plant are dependent on the climatic conditions, the cultivar and the phenological stage (GRATIERI et al., 2013). Because of these, it is interesting to establish for each growth stage and different growing conditions (management and climate) the best composition of the nutrient solution in order to maximize the growth and development characteristics of the plants. With the hydroponic system, it is possible to control the composition of the nutrient solution more efficiently than in soil cultivation, providing proportions of nutrients closer to plant requirements.

For melon, $\mathrm{K}$ and $\mathrm{N}$ are the nutrients most required by the plants (AGUIAR NETO et al., 2014; NEOCLEOUS; SAVVAS, 2016). $\mathrm{K}$ is an important element in the synthesis and translocation of sugars; it allows the good formation of vegetative organs of plants and increases the yield and post-harvest quality of fruit (LESTER; JIFON; MAKUS, 2010). On the other hand, $\mathrm{N}$ benefits the growth of vegetative organs which is positively reflected in the photosynthetic and yield capacity of plants (VAN BUEREN; STRUIK, 2017).

$\mathrm{N}$ and $\mathrm{K}$ do not perform their functions in isolation; on the contrary, they have high interaction with each other. The increase in the $\mathrm{K}$ content in the plant increases the efficiency of $\mathrm{N}$ utilization. In addition, $\mathrm{K}$ acts on the regulation of growth when the excessive availability of $\mathrm{N}$ occurs in the growing medium (HAWKESFORD et al., 2012). Gratieri et al. (2013) observed that the $\mathrm{N}: \mathrm{K}$ ratio of 20:10 mmol $\mathrm{L}^{-1}$ resulted in higher yield of melons grown in a coconut-coir substrate. With hydroponic cultivation, Andriolo et al. (2005) obtained a maximum melon yield with the $\mathrm{N}: \mathrm{K}$ ratio of 19.5: $9.0 \mathrm{mmol} \mathrm{L}^{-1}$. These authors did not modify the treatments according to the phenological growth stage. This type of management is common, in fact, frequently, only one nutrient formulation is used throughout the growth cycle (PEDROSA et al., 2011). However, nutrient uptake by plants is altered according to the development stage.
In view of the lack of information on this subject, this study was carried out with the objective of evaluating the effect of $\mathrm{N}$ and $\mathrm{K}$ concentrations on melons cultivated in nutrient film technique (NFT) hydroponic system, in order to obtain the best $\mathrm{N}: \mathrm{K}$ ratios for the vegetative and reproductive stages.

\section{MATERIAL AND METHODS}

The study was carried out from October 19, 2016 to January 4, 2017 at São Paulo State University "Júlio de Mesquita Filho" (UNESP), Jaboticabal, São Paulo (21 ○ 15'22 "South, $48^{\circ}$ 18 '58" West, and altitude of $575 \mathrm{~m}$ ). The study took place in a greenhouse using the NFT hydroponic system. During the experimental period, the average values for temperature and relative humidity were $34.8{ }^{\circ} \mathrm{C}$ and $46 \%$, maximum values were $39.3{ }^{\circ} \mathrm{C}$ and $89 \%$ and minimum were $20.0{ }^{\circ} \mathrm{C}$ and $45 \%$, respectively.

The study was divided in two phases (experiments), the vegetative stage and the reproductive stage, which received different treatments.

In the vegetative stage, combinations of four $\mathrm{N}$ concentrations $\left(8,11,14\right.$ and $17 \mathrm{mmol} \mathrm{L}^{-1}$ ) and two $\mathrm{K}$ concentrations ( 4 and $5 \mathrm{mmol} \mathrm{L}^{-1}$ ) in the nutrient solution were evaluated. The experimental design used in this stage was a complete randomized block in a $4 \times 2$ factorial scheme with five replicates. The $\mathrm{N}$ and $\mathrm{K}$ concentrations were proposed based on Castellane and Araújo (1994), who recommend 14 and $5.7 \mathrm{mmol}_{\mathrm{c}} \mathrm{dm}^{-3}$, respectively.

At the end of the vegetative stage (first phase), based on the results obtained for growth and nutritional state of the plants, the two best $\mathrm{N}$ concentrations were defined, one for each $\mathrm{K}$ concentration. The other treatments were excluded, and the defined $\mathrm{N}$ concentrations were used as treatments in the second phase of the experiment.

In the reproductive stage (second phase $11 / 29 / 2016$ ), the treatments consisted of the two best $\mathrm{N}$ concentrations from the first phase (14 and 17 mmol L ${ }^{-1}$ ) and two new $\mathrm{K}$ concentrations (4.5 and $\left.9.0 \mathrm{mmol} \mathrm{L}^{-1}\right)$. These concentrations were based according to the $\mathrm{K}$ concentration used by Castellane and Araújo (1994) and the important role of this nutrient at this stage. This part of the experiment used a $2 \times 2$ factorial scheme, with the same experimental design and number of replicates adopted in the previous phase.

The experimental unit for both phases consisted of five melon plants grown in a PVC channel cut longitudinally which was $2 \mathrm{~m}$ in length and $0.2 \mathrm{~m}$ in diameter. In addition, a 150 -L tank with a submerged pump (Power Head CX-300 model; flow rate $1000 \mathrm{~L} \mathrm{~h}^{-1}$ ) was used. The PVC channel was covered with Tetrapak ${ }^{\circledR}$ to prevent the effect of solar radiation on the nutrient solution. The useful

Rev. Caatinga, Mossoró, v. 33, n. 1, p. 108 - 115, jan. - mar., 2020 
area was represented by the three central melon plants; one plant at each end was excluded.

In both phases, the $\mathrm{N}$ and $\mathrm{K}$ concentrations in the nutrient solutions followed levels established for each treatment. The concentrations of the other nutrients were based on the proposal of Castellane and Araújo (1994) for the cultivation of melon in NFT. The concentrations of macronutrients (in $\mathrm{mg} \mathrm{L}^{-}$ $\left.{ }^{1}\right)$ were: $39(\mathrm{P}) ; 156(\mathrm{Ca}) ; 24(\mathrm{Mg})$ and $32(\mathrm{~S})$. The concentrations of micronutrients (in $\mathrm{mg} \mathrm{L}^{-1}$ ) were: $0.3(\mathrm{~B}) ; 2.2(\mathrm{Fe}) ; 0.6(\mathrm{Mn}) ; 0.3(\mathrm{Zn}) ; 0.05(\mathrm{Cu})$ and 0.05 (Mo).

The melon hybrid used was 'Fantasy' of the net melon group. Seedlings were sown in a $5 \times 5 \times 3$ $\mathrm{cm}$ block of phenolic foam, previously washed in running water for $10 \mathrm{~min}$. Nine days after sowing, when the seedlings displayed expanded cotyledons, they were transferred to the initial growth PVC channels $(5 \mathrm{~cm}$ in diameter) in an NFT hydroponic system. The seedlings remained in this system for eleven days. During this period, plants received a complete nutrient solution, recommended by Castellane and Araújo (1994) for the hydroponic cultivation of melon plants.

The transfer to the final channel was carried out at the two-leaf stage ( 20 days after sowing). The spacing of plants adopted was $1.0 \times 0.4 \mathrm{~m}$. Plants were maintained with one main stem which was vertically tutored using plastic polythene strips. The apical bud was eliminated at the 22nd node. Lateral bud thinning was carried out until the 10th node, keeping the 11th and 12th node for fruiting and performing the thinning of subsequent nodes. Pollination was performed manually in the morning. After fixation of two fruits per plant, small fixed fruits were eliminated. In the lateral stems, the removal of the apical bud was conducted two leaves after the fruit.

Phosphoric acid and sodium hydroxide were used to maintain the nutrient solution between $\mathrm{pH}$ 6.0 and 6.5. The water was replenished daily to restore the initial volume of the tank. The nutrient solution was renewed when there was a reduction of $25 \%$ and $75 \%$ of the initial electrical conductivity (EC) in the vegetative and reproductive stage, respectively. The stock solution used for renewal contained the same nutrient concentration as the initial solution used for the corresponding treatment.

The activation of pumps used to recirculate the nutrient solution was controlled by means of a timer, starting at 7:30 a.m. and ending at 6:30 p.m. without interruption. sowing.

Harvesting was carried out at 78 days after

At the end of the first phase (11/25/2016), the following characteristics were evaluated: a) leaves per plant (LP); b) internode length (IL) (cm); c) leaf area (LA) $\left(\mathrm{cm}^{2}\right.$ per plant): it was used a nondestructive method, obtaining the leaf area of each leaf of the plant by means of the equation $\mathrm{AF}=$ $0.826 \mathrm{~L}^{1.89}$, proposed by Nascimento et al. (2002). The measurement of the leaf width was performed using a metric ruler; d) stem diameter (SD) (mm): obtained through a digital caliper, $4 \mathrm{~cm}$ from the base of the plant; e) height $(\mathrm{H})(\mathrm{cm})$; $\mathrm{f})$ macronutrient content in the diagnostic leaf $\left(\mathrm{g} \mathrm{kg}^{-1}\right)$ : the 5th leaf from the tip was collected, excluding the apical tuft, following the recommendation proposed by Trani and Raij (1997). The leaves were then washed, dried, ground and prepared for determination of the $\mathrm{N}, \mathrm{P}, \mathrm{K}, \mathrm{Ca}, \mathrm{Mg}$ and $\mathrm{S}$ content, according to the methodology proposed by Miyazawa et al. (2009).

At the end of the second phase (01/04/2019), the following characteristics were evaluated: a) leaf area (LA) $\left(\mathrm{cm}^{2}\right.$ per plant): obtained using a LICOR 3100 electronic meter; (b) fruit mass (FM) (kg); c) marketable yield (MY) $\left(\mathrm{t} \mathrm{ha} \mathrm{ha}^{-1}\right)$ : this involved individual fruits weighing more than $400 \mathrm{~g}$ and without visible defects, as suggested by Nerson et al. (1989); d) total yield (TY) $\left(\mathrm{t} \mathrm{ha}^{-1}\right)$.

The quality characteristics of the first and second fruits evaluated were: a) soluble solids (SS) $\left({ }^{\circ}\right.$ Brix); b) pulp firmness (F) (expressed in Newtons $(\mathrm{N})$ ) : determined using a digital penetrometer; c) mesocarp thickness $(\mathrm{T})(\mathrm{mm})$ : determined using a digital caliper; d) netting degree of the coat (ND): determined by visual evaluation, according to the scale proposed by Rizzo (2004), namely 1 (weak), 2 (medium) and 3 (intense).

Data were submitted to analysis of variance with an F-test at 5\% of probability using the AGROESTAT program (BARBOSA; MALDONADO JÚNIOR, 2015). Regression analysis was performed of all characteristics evaluated at the vegetative stage, choosing the equation with the highest coefficient of determination.

\section{RESULTS AND DISCUSSION}

\section{Vegetative stage}

The number of LP and LA were both affected by $\mathrm{N}$ concentration, so that higher $\mathrm{N}$ concentrations in the nutrient solution resulted in linear increments in both variables. The maximum values were 13.9 leaves and $2676.5 \mathrm{~cm}^{2}$ per plant with a $\mathrm{N}$ concentration of $17 \mathrm{mmol} \mathrm{L}^{-1}$ (Figure 1A). 


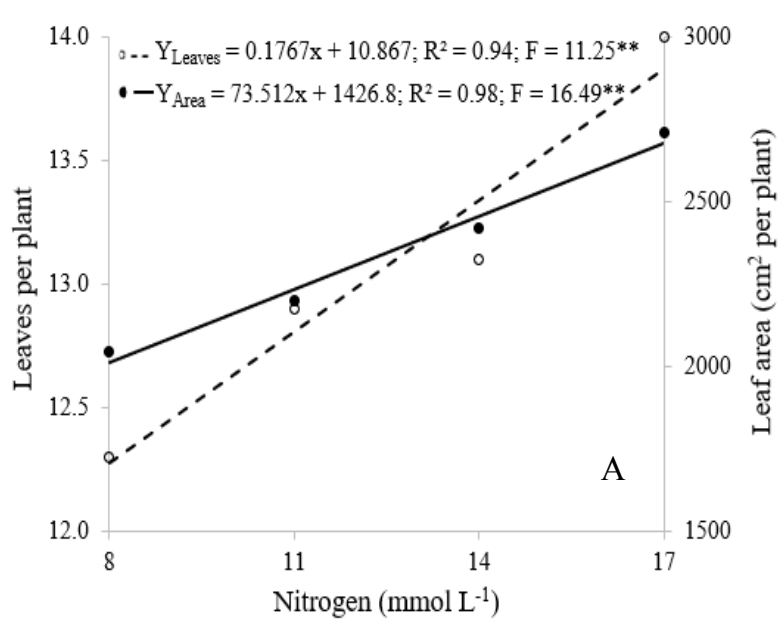

Figure 1. Leaves per plant and leaf area (A) and heigh concentrations in the vegetative stage.

The higher the LP, the greater was the LA per plant. This increase may be associated with both the increase in the number of leaves and the increase in the width and length of the leaves, resulting from the increase of $\mathrm{N}$ concentrations in the nutrient-solution. The LA obtained with $17 \mathrm{mmol} \mathrm{L}^{-1}$ of $\mathrm{N}$ was $33 \%$ higher than that obtained with $8 \mathrm{mmol} \mathrm{L}^{-1}$. Other authors also observed increase in the LA in melon with increasing $\mathrm{N}$ concentrations in the culture medium (EL-YAZIED et al., 2012; GRATIERI et al., 2013). $\mathrm{N}$ is part of the composition of several organic compounds which are fundamental to the physiological, biochemical and metabolic functions of plants (KANT, 2017). Consequently, limitation in the supply of $\mathrm{N}$ has a negative effect on plant growth and development.

The $\mathrm{H}$ of plants was influenced by the interaction of $\mathrm{N}$ and $\mathrm{K}$. The maximum $\mathrm{H}(89.54 \mathrm{~cm})$ was obtained with the maximum $\mathrm{N}$ and $\mathrm{K}$

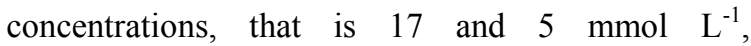
respectively (Figure 1B). This positive effect on plant growth can be explained by the synergistic interaction between $\mathrm{N}$ and $\mathrm{K}$, wherein the increase of $\mathrm{K}$ increases the efficiency of $\mathrm{N}$ utilization, since it improves the absorption and assimilation of $\mathrm{N}$. The presence of adequate rates of $\mathrm{K}$ in the medium is fundamental because $\mathrm{K}$ activates nitrate reductase being extremely important for protein synthesis (HAWKESFORD et al., 2012).

The SD was not influenced by the treatments and the mean value reported was $8.4 \mathrm{~mm}$. The IL was influenced only by the $\mathrm{K}$ concentration. Plants grown with $5 \mathrm{mmol} \mathrm{L}^{-1}$ of $\mathrm{K}$ showed greater IL than plants with lower $\mathrm{K}$ concentrations. It can be due to the fact that plants with low content of $\mathrm{K}$ reduce the synthesis of proteins and accumulate high contents of low weight compounds (nitrates, amines, soluble sugars, and amino acids) leading to a decrease in the plant growth and productivity.

The foliar $\mathrm{N}$ content was influenced only by

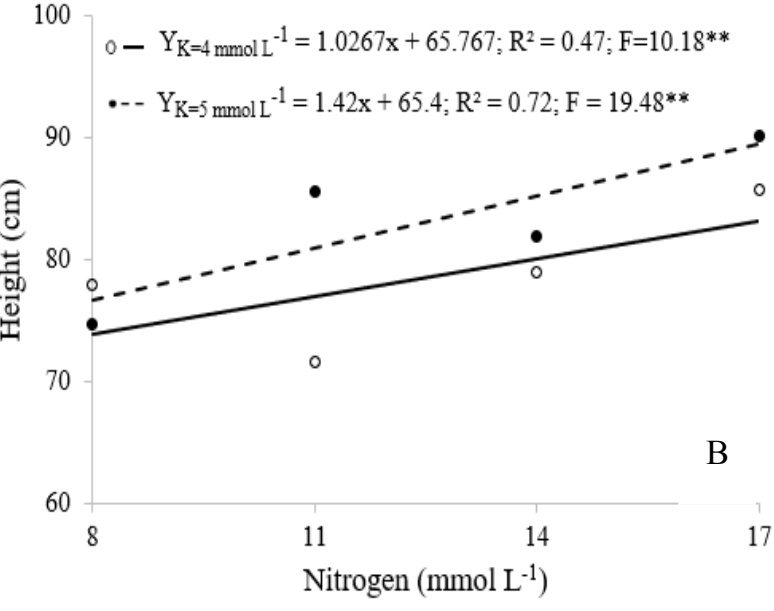

(B) of melon plants in response to different nitrogen the $\mathrm{N}$ concentration in the nutrient solution, with a maximum content $\left(48.8 \mathrm{~g} \mathrm{~kg}^{-1}\right)$ occurring with the maximum $\mathrm{N}$ concentration $\left(17 \mathrm{mmol} \mathrm{L}^{-1}\right)$ (Figure $2 \mathrm{~A})$. This content was $14 \%$ higher than that observed in plants which received the lowest concentration of $\mathrm{N}$. However, with all treatments, the $\mathrm{N}$ content was within the adequate range proposed by Trani and Raij (1997), namely between 25 and $50 \mathrm{~g} \mathrm{~kg}^{-1}$. The increase in plant growth was directly related to plants with higher $\mathrm{N}$ content.

The $\mathrm{P}$ content was influenced in isolation by the $\mathrm{N}$ and $\mathrm{K}$ concentrations in the nutrient solution. The $\mathrm{P}$ content increased linearly with increasing $\mathrm{N}$ content of the nutrient solution (Figure 2B). This is probably due to the increase of the $\mathrm{NH}_{4}^{+}$ concentration in nutrient solutions which are richer in $\mathrm{N}$, which favors the uptake of the $\mathrm{H}_{2} \mathrm{PO}_{4}{ }^{-}$anion, showing a synergistic effect between nitrogen and phosphorus (PRADO, 2008). The increase of 4 to $5 \mathrm{mmol} \mathrm{L}^{-1}$ of $\mathrm{K}$ in the nutrient solution caused a $10 \%$ reduction of the $\mathrm{P}$ content ( 7.66 to $6.88 \mathrm{~g} \mathrm{~kg}^{-1}$ ).

The $\mathrm{P}$ content of leaves with treatments of $4 \mathrm{mmol} \mathrm{L}^{-1}$ of $\mathrm{K}$ and 11,14 and $17 \mathrm{mmol} \mathrm{L}^{-1}$ of $\mathrm{N}$ were above the normal range reported by Trani and Raij (1997), who recommended between 3 and $7 \mathrm{~g} \mathrm{~kg}^{-1}$. From an economic point of view, it is recommended that growers do not adopt this type of nutritional management, to avoid high levels of the nutrients. Such high levels correspond to a range in which the melon presents luxury consumption, which means that the plants absorb the nutrient above requirements without any implications for increased productivity (DAMASCENO et al., 2012).

Leaf $\mathrm{K}$ content was not influenced by the interaction between the nutrients, but it responded to $\mathrm{N}$ and $\mathrm{K}$ concentrations in isolation. The highest $\mathrm{K}$ content $\left(39.5 \mathrm{~g} \mathrm{~kg}^{-1}\right)$ occurred with a treatment that resulted in the lowest plant growth, namely an $\mathrm{N}$ concentration of $8 \mathrm{mmol} \mathrm{L}^{-1}$ (Figure $2 \mathrm{C}$ ). 

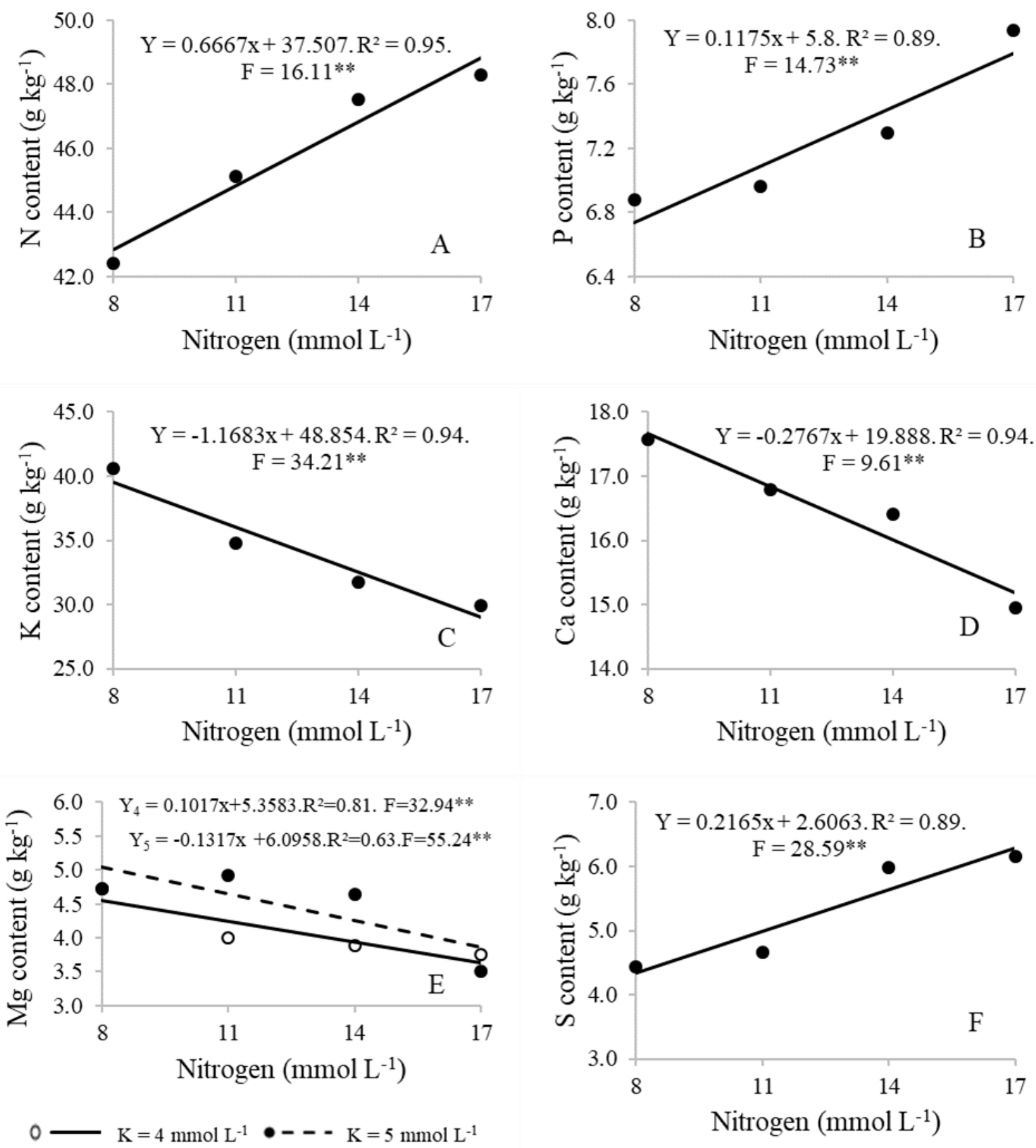

Figure 2. Nitrogen (A), phosphorus (B), potassium (C), calcium (D), magnesium (E) and sulfur (F) content of leaves of melon plants in response to different nitrogen concentrations in the nutrient solution at the vegetative stage.

Leaf $\mathrm{K}$ content was not influenced by the interaction between the nutrients, but it responded to $\mathrm{N}$ and $\mathrm{K}$ concentrations in isolation. The highest $\mathrm{K}$ content $\left(39.5 \mathrm{~g} \mathrm{~kg}^{-1}\right)$ occurred with a treatment that resulted in the lowest plant growth, namely an $\mathrm{N}$ concentration of $8 \mathrm{mmol} \mathrm{L}^{-1}$ (Figure 2C).

The decrease of $\mathrm{K}$ content with the increase of $\mathrm{N}$ concentrations in the nutrient solution may have resulted from competition between the $\mathrm{NH}_{4}{ }^{+}$and $\mathrm{K}^{+}$ ions (DANTAS NETO et al., 2013). In nutrient solutions with higher $\mathrm{N}$ concentrations, there were higher $\mathrm{NH}_{4}{ }^{+}$concentrations which were required by higher amounts of ammonium nitrate used to meet the higher $\mathrm{N}$ concentrations in the nutrient solution.

The $\mathrm{K}$ content of leaves with a $\mathrm{K}$ concentration in the nutrient solution of $4 \mathrm{mmol} \mathrm{L}^{-1}$ was $17 \%$ higher than with $5 \mathrm{mmol} \mathrm{L}^{-1}$. With all treatments, the $\mathrm{K}$ content was within the appropriate range of 25 to $40 \mathrm{~g} \mathrm{~kg}^{-1}$ (TRANI; RAIJ, 1997).

The maximum leaf $\mathrm{Ca}$ content was observed at the lowest $\mathrm{N}$ concentration in the nutrient solution (Figure 2D). With all treatments, levels of this nutrient were below the range considered adequate by Trani and Raij (1997), namely between 25 and 50 $\mathrm{g} \mathrm{kg}^{-1}$. However, no symptoms of deficiency were observed. The decrease of the $\mathrm{Ca}$ content as the 
concentration of $\mathrm{N}$ increased can be due to the competition between $\mathrm{NH}_{4}^{+}$with $\mathrm{Ca}^{2+}$.

The leaf $\mathrm{Mg}$ content was influenced by the interaction between the $\mathrm{N}$ and $\mathrm{K}$ concentrations in the nutrient solution. With both $\mathrm{K}$ concentrations, the $\mathrm{Mg}$ content decreased when the $\mathrm{N}$ concentration was increased. With the highest $\mathrm{K}$ concentration in the nutrient solution, greater leaf $\mathrm{Mg}$ content was observed, regardless of the $\mathrm{N}$ concentration. The minimum $\mathrm{Mg}$ content occurred with the highest $\mathrm{N}$ $\left(17 \mathrm{mmol} \mathrm{L}^{-1}\right)$ and the lowest $\mathrm{K}\left(4 \mathrm{mmol} \mathrm{L}^{-1}\right)$ concentrations in the nutrient solution (Figure 2E). Leaf $\mathrm{Mg}$ content with most of the treatments was below the range considered adequate by Trani and Raij (1997), namely between 5 and $12 \mathrm{~g} \mathrm{~kg}^{-1}$; the only exception was with 8 and $5 \mathrm{mmol} \mathrm{L}^{-1}$ of $\mathrm{N}$ and $\mathrm{K}$ concentrations in the nutrient solution, respectively. Although no symptoms of $\mathrm{Mg}$ deficiency were observed.

The leaf S content was influenced only by the $\mathrm{N}$ concentration. At $\mathrm{N}$ concentrations of 11,14 and $17 \mathrm{mmol} \mathrm{L}^{-1}$, there were increases in $\mathrm{S}$ content of 15 , 30 and $45 \%$, respectively, in relation to the lower $\mathrm{N}$ concentration (Figure 2F). There is a synergistic interaction between $\mathrm{N}$ and $\mathrm{S}$, resulting in a favorable effect on the plant development. The leaf S content in all treatments were above the range considered adequate by Trani and Raij (1997), that is between 2 and $3 \mathrm{~g} \mathrm{~kg}^{-1}$.

Considering that there was no interaction between the $\mathrm{N}$ and $\mathrm{K}$ concentrations in terms of most of the characteristics evaluated at the end of the vegetative stage. And that, when there was interaction between the factors, the $\mathrm{H}$ and the $\mathrm{Mg}$ content responded to both $\mathrm{K}$ concentrations in the same way as to the increment of the $\mathrm{N}$ concentration in the nutrient solution, and that greater H, LP and LA were higher with the two higher $\mathrm{N}$ concentrations at both $\mathrm{K}$ concentrations. Then, the $\mathrm{N}$ concentrations of 14 and $17 \mathrm{mmol} \mathrm{L}^{-1}$ were considered to be the most appropriate concentrations associated with $5 \mathrm{mmol} \mathrm{L}^{-1}$ of $\mathrm{K}$, because they favor higher $\mathrm{Mg}$ content and greater IL and $\mathrm{H}$. These concentrations provide $\mathrm{N}: \mathrm{K}$ ratios of $1: 1$ and $1.2: 1$, respectively.

\section{Reproductive stage}

The LA was not affected by the different treatments and the mean value was $12,311.92 \mathrm{~cm}^{2}$ per plant. This result can be attributed to the changes on the pattern of the photosynthate flow with the entrance to the reproductive stage (photosynthate is translocated from leaves to fruits); to the pruning of the main stem which was performed $10 \mathrm{~cm}$ after the 22nd node; to the NFT method with recirculation of the nutrient solution, and the system used for replenishing the nutrient solution. The observed LA value was higher than that reported by Gratieri et al. (2013) with coconut-coir substrate. These authors reported an isolated effect of $\mathrm{N}$, with $\mathrm{AF}$ values of 7063.00 and $9353.00 \mathrm{~cm}^{2}$ per plant at $\mathrm{N}$ concentrations of 8 and $20 \mathrm{mmol} \mathrm{L}^{-1}$, respectively.

The production characteristics were not influenced by the treatments. The reported mean values for FM, MY and TY were $1.55 \mathrm{~kg}, 67.91 \mathrm{tha}$ ${ }^{1}$ and $77.27 \mathrm{t} \mathrm{ha}^{-1}$, respectively. MY was higher than values report by other authors (CAMPELO et al., 2014; WANG et al., 2017). Andriolo et al. (2005), evaluating the influence of $\mathrm{N}$ and $\mathrm{K}$ on fertigated cultivation of the 'Torreon' hybrid, reported a maximum TY of $6.59 \mathrm{~kg} \mathrm{~m}^{-2}\left(65.9 \mathrm{t} \mathrm{ha}^{-1}\right)$, with a $\mathrm{N}: \mathrm{K}$ ratio of 19.5:9.0 $\mathrm{mmol} \mathrm{L}^{-1}$.

The lack of response of melon plants to the $\mathrm{N}$ and $\mathrm{K}$ concentrations in terms of productive characteristics may be due to the recirculation of the nutrient solution, recomposition of the EC and renewal of the nutrient solution approximately every seven days, making the lowest concentration of $\mathrm{N}$ and $\mathrm{K}$ sufficient for the plants. Higher $\mathrm{N}$ and $\mathrm{K}$ concentrations at this stage may have contributed to higher nutrient content of the plants without translating this into production, which characterizes luxury consumption. Purquerio, Cecílio Filho and Barbosa (2003) and Costa et al. (2004), without making changes to the $\mathrm{N}: \mathrm{K}$ ratios between the phenological growth stages, did not find any effects on production of melons with $\mathrm{N}$ concentrations of $80,140,200$, and $300 \mathrm{mg} \mathrm{L}^{-1}$ and $\mathrm{K}$ concentrations of $66,115.5,165$ and $247.5 \mathrm{mg} \mathrm{L}^{-1}$, respectively.

With regard to the quality characteristics of the first and second fruits, namely SS, F, T and ND, these were not influenced by the $\mathrm{N}$ and $\mathrm{K}$ concentration in the nutrient solution. The results reported are similar to those of Costa et al. (2004) and Purquerio and Cecílio Filho (2005), who also did not observe differences in the SS content of hydroponically grown melon fruits with increases in $\mathrm{K}$ and $\mathrm{N}$ concentrations in the nutrient solution, respectively. The mean values for SS were 9.2 and $8.9^{\circ}$ Brix for the first and second fruits, respectively. The first and second melon fruits had SS contents below the potential of the hybrid used (14 to $15^{\circ}$ Brix), given that the second fruit did not meet export standards which require a minimum content of $9^{\circ}$ Brix (SILVA; ALVES; SANTOS, 2008). This result can be attributed to the continuous circulation of the nutrient solution, without interruption, which is necessary to confer some stress on the plant and promote concentration of SS in the fruit (MELO et al., 2012; WANG et al., 2017).

The $\mathrm{F}$ of the fruits had mean values of 19.5 and $18.3 \mathrm{~N}$ for the first and second fruits, respectively. The $\mathrm{F}$ is a fundamental attribute in post -harvest handling, since it confers resistance to possible mechanical injuries which may occur during the transport and handling processes (CHAVES et al., 2014; BIANCHI et al., 2016). Several values for $\mathrm{F}$ have been reported in the literature for melon. Dalastra et al. (2016) reported a mean $F$ value of 
$31.96 \mathrm{~N}$ for the net melon. Lower values were reported by Melo et al. (2012), ranging from 13 to 27 N.

The mean values for $\mathrm{T}$ were 34.6 and 34.2 $\mathrm{mm}$ for the first and second fruits, respectively. A thicker mesocarp is a desirable characteristic, since it increases the edible part of the fruit and, thus, improves its quality. Silva et al. (2014), evaluating the effect of $\mathrm{N}$ and $\mathrm{K}$ concentrations on the qualitative characteristics of the net melon grown in soil, showed an isolated effect of the nutrients; maximum $\mathrm{T}$ (31.83 and $30.70 \mathrm{~mm}$ ) occurred with $\mathrm{N}$ and $\mathrm{K}$ concentrations of 160 and $240 \mathrm{mg} \mathrm{dm}$, respectively.

The mean ND for both first and second fruits was grade 2.4. Based on the literature, this value was lower than that reported by other authors (MELO et al., 2012; VARGAS et al., 2013). It is desirable that the fruits exhibit an intense ND, because it makes them more attractive to the consumer market. However, in this case, the low grade was not considered significant enough to adversely affect commercialization.

Due to the absence of a significant effect on all characteristics evaluated at the end of the second stage, the two lowest concentrations of $\mathrm{N}: \mathrm{K}(14: 4.5)$ were considered to be the most appropriate. This combination gave an $\mathrm{N}: \mathrm{K}$ ratio of 1.1: 1 .

\section{CONCLUSION}

The recommended $\mathrm{N}: \mathrm{K}$ ratio for the vegetative stage of melon growth is $17 \mathrm{mmol} \mathrm{L}^{-1}$ of $\mathrm{N}$ and $5 \mathrm{mmol} \mathrm{L}^{-1}$ of $\mathrm{K}$ and, for the reproductive stage, $14 \mathrm{mmol} \mathrm{L}^{-1}$ of $\mathrm{N}$ and $4.5 \mathrm{mmol} \mathrm{L}^{-1}$ of $\mathrm{K}$.

\section{ACKNOWLEDGMENTS}

Authors thank CAPES for the scholarship granted to the first author.

\section{REFERENCES}

AGUIAR NETO, P. et al. Growth and nutrient accumulation in melon crop in Baraúna-RN and Petrolina-PE. Revista Brasileira de Fruticultura, 36: 556- 567, 2014.

ANDRIOLO, J. L. et al. Produtividade e qualidade de frutos de meloeiro cultivado em substrato com três doses de solução nutritiva. Ciência Rural, 35: 781-787, 2005.

BARBOSA, J. C.; MALDONADO JÚNIOR, W. AgroEstat: sistema para análises estatísticas 501 de ensaios agronômicos. 1 ed. Jaboticabal: Gráfica
Multipress Ltda, 2015. 396 p.

BIANCHI, T. et al. Textural properties of different melon (Cucumis melo L.) fruit types: Sensory and physical-chemical evaluation. Scientia Horticulturae, 201: 46-56, 2016.

VAN BUEREN, E. T. L.; STRUIK, P. C. Diverse concepts of breeding for nitrogen use efficiency. A review. Agronomy for Sustainable Development, 37: 37-50, 2017

CAMPELO, A. R. et al. Manejo da cultura do melão submetida a frequências de irrigação e fertirrigação com nitrogênio. Horticultura Brasileira, 32: 138144,2014

CASTEllane, P. D.; ARAúJO, J. A. C. Cultivo sem solo: hidroponia. 3. ed. Jaboticabal, SP: FUNEP, 1994. 43 p.

CHAVES, S. W. P. et al. Conservação de melão Cantaloupe cultivado em diferentes doses de $\mathrm{N}$ e K. Horticultura Brasileira, 32: 468-474, 2014.

COSTA, C. C. et al. Concentração de potássio na solução nutritiva e a qualidade e número de frutos de melão por planta em hidroponia. Ciência Rural, 34: 731-736, 2004

DAMASCENO, A. P. A. B. et al. Crescimento e marcha de absorção de nutrientes do melão cantaloupe tipo "Harper" fertirrigado com doses de N e K. Revista Caatinga, 25: 137-146, 2012.

DANTAS NETO, J. et al. Teores de macronutrientes em folhas de goiabeira fertirrigada com nitrogênio. Revista Brasileira de Engenharia Agrícola e Ambiental, 17: 962-968, 2013.

DALASTRA, G. M. et al. Produção e qualidade de três tipos de melão, variando o número de frutos por planta. Revista Ceres, 63: 523-531, 2016.

DEUS, J. A. L. et al. Fertilizer recommendation system for melon based on nutritional balance. Revista Brasileira Ciência do Solo, 39: 498-511, 2015.

EL-YAZIED, A. A. et al. Response of cantaloupe hybrids to nitrogen fertilization levels under natural infection with Monosporascus cannonballus. Australian Journal of Basic and Applied Sciences, 6: 1-11, 2012

FOOD AND AGRICULTURE ORGANIZATION FAO. Food and agriculture data. Available in: $<$ http://www.fao.org/home/en/> Access in: December 31, 2017. 
GRATIERI, L. A. et al. Nitrogen and potassium concentrations in the nutrients solution for melon plants growing in coconut fiber without drainage. The Scientific World Journal, 2013: 1-10, 2013.

HAWKESFORD, M. et al. Functions of Macronutrients. In: Marschner, P. (Ed.) Marschner's Mineral Nutrition of Higher Plants. 3. Ed. Cambridge: Academic Press, 2012, cap. 6, p. 135-189.

KANT, S. Understanding nitrate uptake, signaling and remobilisation for improving plant nitrogen use efficiency. Seminars in Cell \& Developmental Biology, 74: 89-96, 2017.

LESTER, G. E.; JIFON, J. L.; MAKUS, D. J. Impact of Potassium Nutrition on Postharvest Fruit Quality: Melon (Cucumis Melo L) Case Study. Plant and Soil, 335: $117-331,2010$.

MELO, D. M. et al. Produção e qualidade de melão rendilhado sob diferentes substratos em cultivo protegido. Revista Caatinga, 25: 58-66, 2012.

MIYAZAWA, M. et al. Análises químicas de tecido vegetal. In: SILVA, F. C. (Eds.). Manual de análises químicas de solos, plantas e fertilizantes. 2. ed. Brasília, DF: EMBRAPA, 2009. 190-223 p.

NASCIMENTO, I. B. et al. Estimativa da área foliar do meloeiro. Horticultura Brasileira, 20: 555-558, 2002.

NEOCLEOUS, D.; SAVVAS, D. $\mathrm{NaCl}$ accumulation and macronutrient uptake by a melon crop in a closed hydroponic system in relation to water uptake. Agricultural Water Management, 165: 22-32, 2016.

NERSON, H. et al. Paclobutrazol - a plant growth retardant for increasing yield and fruit quality in muskmelon. Journal of the American Society Horticultural Science, 114: 762-766, 1989.

PEDROSA, A. W. et al. Influence of the $\mathrm{N} / \mathrm{K}$ ratio on the production and quality of cucumber in hydroponic system. Revista Ceres, 58: 619-624, 2011.

PRADO, R. M. Nutrição de plantas. 1. ed. São Paulo, SP: Editora UNESP, 2008. 407 p.

PURQUERIO, L. F. V.; CECÍLIO FILHO, A. B.; BARBOSA, J. C. Efeito da concentração de nitrogênio na solução nutritiva e do número de frutos por planta sobre a produção do meloeiro. Horticultura Brasileira, 21: 186-191, 2003.
PURQUERIO, L. F. V.; CECÍLIO FILHO, A. B. Concentração de nitrogênio na solução nutritiva e número de frutos sobre a qualidade de frutos de melão. Horticultura Brasileira, 23: 831-836, 2005.

RIZZO, A. A. N. Obtenção e avaliação de genótipos de melão rendilhado em ambiente protegido. 2004. 38 f. Tese (Doutorado em Produção Vegetal: Área de Concentração em Melhoramento Genético) - Universidade Estadual Paulista "Júlio de Mesquita Filho", Jaboticabal, 2004.

TRANI, P. E.; RAIJ, B. V. Hortaliças. In: RAIJ, B. van et al. (Eds.). Recomendação de adubação e calagem para o estado de São Paulo. 2. ed. Campinas, SP: IAC, 1997.155-185 p. (Boletim Técnico, 100).

SILVA, E. O.; ALVES, R. E.; SANTOS, E. C. Colheita e pós-colheita na produção integrada de melão. In: BRAGA SOBRINHO R. et al. (Ed.). Produção Integrada de Melão. 1. ed. Fortaleza, CE: Embrapa Agroindústria Tropical, 2008. v. 1, cap. 24, p. $273-284$

SILVA, M. C. et al. Características produtivas e qualitativas de melão rendilhado adubado com nitrogênio e potássio. Revista Brasileira de Engenharia Agrícola e Ambiental, 18: 581-587, 2014.

SUN, M. et al. How to predict the sugariness and hardness of melons: A near-infrared hyperspectral imaging method. Food Chemistry, 218: 413-421, 2017.

VARGAS, P. F. et al. Physicochemical characteristics of experimental net melon hybrids developed in Brazil. Horticultura Brasileira, 31: 351-355, 2013

WANG, J. et al. Effect of soil moisture-based furrow irrigation scheduling on melon (Cucumis melo L.) yield and quality in an arid region of Northwest China. Agricultural Water Management, 179: 167 $-176,2017$.

This work is licensed under a Creative Commons Attribution-CC-BY https://creativecommons.org/licenses/by/4.0/ 